\title{
APPLICATION OF EXPRESS METHODS FOR DETECTION OF SLAUGHTER ANIMALS' MEAT ADULTERATION BY TREATMENT WITH ALKALINE DETERGENTS AND DISINFECTANTS
}

\author{
Bogatko N. M. \\ Bila Tserkva National Agrarian University, Bila Tserkva, Ukraine, e-mail: nadiyabogatko@ukr.net
}

\begin{abstract}
Summary. The article presents the application of the developed patented express methods, which have reliability in tests of $99.9 \%$, and can be used to control dangerous chemical factors to detect adulteration of meat of slaughter animals with sodium bicarbonate solution and alkaline detergents and disinfectants at production facilities and both meat and meat products. According to these express methods, the number of samples for processing the meat of slaughter animals with a solution of sodium bicarbonate using an alcoholic solution of chrome dark blue $(0.5 \%)$ : beef $(n=2)$, pork $(n=2)$ due to the application of meat $\leq 5.0 \%$ and beef $(n=4)$, pork $(n=4)-\geq 5.1 \%$; for treatment with alkaline detergents when using an alcoholic solution of bromothymol blue $(0.04 \%)$ : beef $(n=3)$ due to the application on the surface of meat $\leq 5.0 \%$ and pork $(n=4)$ and goat $(n=4)-\geq 5.1 \%$; for treatment with alkaline disinfectants when using an alcoholic solution of rosolic acid $(0.25 \%)$ : goat $(n=4)$ due to the application on the surface of meat $\leq 5.0 \%$ and beef $(n=5)$ and pork $(n=4)-\geq 5.1 \%$; for treatment with alkaline disinfectants when using an alcoholic solution of chrome dark blue $(0.3 \%)$ : beef $(n=5)$ and pork $(n=4)$; for treatment with alkaline detergents when using an alcoholic solution of bromocresol green $(0.01 \%)$ : pork $(n=5)$, beef $(n=4)$ and lamb $(n=3)$
\end{abstract}

Keywords: beef, pork, lamb, goat, meat control, adulteration, alkaline detergents and disinfectants

Introduction. State risk-based control involves the detection of adulteration of meat of slaughter animals for the establishment of a dangerous chemical factor, namely alkaline detergents and disinfectants due to violations of temperature conditions and shelf life for the production and circulation of raw meat (Amaral et al., 2016).

Therefore, it is necessary to adhere to the temperature regimes for the storage and sale of food products following established regulatory requirements (Aksu, Kaya and Ockerman, 2005). Violation of the shelf life of slaughter meat increases the contamination with microorganisms, which leads to spoilage and loss of consumer properties of the food product (Odewade, Oyelami and Fasogbon, 2018). The adulteration of meat from slaughter animals with detergents and disinfectants is a social problem due to the violation of sanitary and hygienic requirements for production and circulation at facilities (Manning and Soon, 2014). The HACCP system prevents the control of the occurrence of hazards in the food chain by establishing critical control points (Fotina et al., 2016).

These issues have become especially relevant for the implementation of HACCP, VACCP, TACCP systems at the facilities for the production and circulation of meat of slaughter animals - production facilities, wholesale bases, supermarkets, agri-food markets (Milios, Drosinos and Zoiopoulos, 2012; Hulebak and Schlosser, 2002).

Every year the problem of recognizing the safety of meat of slaughter animals becomes more urgent, so it is necessary to develop new methods of identification of this raw material (Aida etal., 2005; Carr, Scheffler and Johnson, 2017).

Therefore, scientists need to develop rapid methods for controlling the safety and quality of slaughter meat during production and circulation, so that the consumer is confident in choosing high-quality food.

Therefore, our research on the detection of adulteration of slaughter meat in agri-food markets and supermarkets using the developed express methods is relevant.

The work aimed to develop and apply express methods for the detection of adulteration of meat of slaughter animals with sodium bicarbonate solution and alkaline detergents and disinfectants.

Materials and methods. The research material was beef, pork, lamb, and goat, which were selected from slaughterhouse meat production facilities, wholesale bases, and sales in agri-food markets and supermarkets. Determination of adulteration of meat of slaughter animals by treatment with sodium bicarbonate solution and alkaline detergents and disinfectants was performed according to the patented in Ukraine methods (Bogatko et al., 2017a, 2017b; Bogatko, Fotina and Yatsenko, 2019a, 2019b, 2019c).

Results and discussion. Express methods are designed to establish the safety and quality of meat of slaughter animals - beef, pork, lamb, goat for detection of treatment with sodium bicarbonate solution and alkaline detergents and disinfectants for elimination of signs of spoilage and reduction of microflora contamination to extend the shelf life in production laboratories, facilities for the production, processing, sale and storage of meat of slaughter animals, supermarkets, wholesale depots, shops, state laboratories of veterinary medicine and testing laboratories of veterinary and sanitary examination in agri-food markets using chemical reagents. The reliability of the developed patented methods is $99.9 \%$. 
The essence of the method of detecting intentional treatment with sodium bicarbonate solution of meat of slaughter animals is to use an alcoholic solution of chrome dark blue with a mass concentration of $0.5 \%$, which when interacting with sodium bicarbonate forms a compound from light purple to dark purple depending on the amount treated solution, respectively $-\leq 5.0 \%$ and $\geq 5.1 \%$, which will ensure the reliability of the results for determining the safety and quality of meat (Bogatko, Fotina and Yatsenko, 2019a, 2019b, 2019c).

The task of the developed express method was solved by applying using a graduated pipette $0.1-0.2 \mathrm{~cm}^{3}$ of an alcoholic solution of chrome dark blue with a mass concentration of $0.5 \%$ to the surface of pork, beef, lamb, goat with an area of $2.0 \times 2.5 \mathrm{~cm}$, and after $1-2 \mathrm{~s}$ we detected the presence of pale pink color (negative reaction) - in the absence of treatment of meat with sodium bicarbonate or the presence of light purple to dark purple color (positive reaction) - depending on the amount of sodium bicarbonate used for treatment, respectively $-\leq 5.0 \%$ and $\geq 5.1 \%$.

The stability of indicators on the intensity of the violet color of varying intensity depending on the quantity of addition of sodium bicarbonate: light violet color $\leq 5.0 \%$ (positive reaction); dark purple color $-\geq 5.1 \%$ (positive reaction) or the presence of pale pink color (negative reaction) when establishing the treatment of meat of slaughter animals with sodium bicarbonate solution was $99.9 \%$. Also, more reliable data - in 99.0-99.5\% were obtained in comparison with the method of determining the content of amino-ammonia nitrogen and in $98.9-99.9 \%$ - in the method of determining the content of microorganisms in meat (Bogatko, Konstantinov and Bogatko, 2016; SDVMMAPU, 2002).

Studies have shown that meat from slaughter animals was treated with sodium bicarbonate solution according to color intensity in 31 samples: 10 samples of pork, 12 samples of beef, 4 samples of lamb, 5 samples of goat. The research results are presented in the Table 1.

Table 1 - Detection of meat of slaughter animals treated with a solution of sodium bicarbonate by color intensity using chrome dark blue $(\mathrm{n}=31)$

\begin{tabular}{|c|c|c|c|}
\hline \multirow{3}{*}{$\begin{array}{l}\text { Type } \\
\text { of } \\
\text { meat }\end{array}$} & \multicolumn{3}{|c|}{ Indicators of color intensity } \\
\hline & \multicolumn{2}{|c|}{$\begin{array}{c}\text { adulteration } \\
\text { (positive reaction) }\end{array}$} & $\begin{array}{c}\text { no adulteration } \\
\text { (negative }\end{array}$ \\
\hline & $\begin{array}{c}\text { light purple } \\
\text { color } \\
(\leq 5.0 \%)\end{array}$ & $\begin{array}{c}\text { dark purple } \\
\text { color } \\
(\geq 5.1 \%)\end{array}$ & $\begin{array}{l}\text { pale } \\
\text { pink } \\
\text { color }\end{array}$ \\
\hline Pork, $\mathrm{n}=10$ & $\mathrm{n}=2$ & $\mathrm{n}=4$ & $\mathrm{n}=4$ \\
\hline Beef, $n=12$ & $\mathrm{n}=2$ & $\mathrm{n}=4$ & $\mathrm{n}=5$ \\
\hline Lamb, $\mathrm{n}=4$ & $\mathrm{n}=1$ & $\mathrm{n}=1$ & $\mathrm{n}=2$ \\
\hline Goat, $n=5$ & $\mathrm{n}=1$ & $\mathrm{n}=1$ & $\mathrm{n}=3$ \\
\hline
\end{tabular}

Studies have shown that the largest number of samples treated with sodium bicarbonate solution by applying $\leq 5.0 \%$ was in beef $(\mathrm{n}=2)$ and pork $(\mathrm{n}=2)$, and by applying $\geq 5.1 \%$ was in pork $(n=4)$ and beef $(n=4)$.

In the absence of adulteration with alkaline detergents - the absence of purple color of varying intensity, but in the presence of pale pink color (negative reaction) in 5 samples of beef, 4 samples of pork, 3 samples of goat, and 2 samples of lamb.

The essence of the method of detection of intentional treatment with alkaline disinfectants of meat of slaughter animals is to use an alcoholic solution of chrome dark blue with a mass concentration of $0.3 \%$, which when interacting with disinfectants forms a light purple compound that will ensure the reliability of safety results and meat quality (Bogatko, Fotina and Yatsenko, 2019b).

The task of developing the express method was solved by the fact that the cut surface of the muscle tissue of pork, beef, lamb, goat, in the amount of 2.0-2.1 g was crushed with scissors, then placed in a flask, poured distilled water in the amount of $8.0-8.1 \mathrm{~cm}^{3}$ (ratio 1:4). The meat-water extract was infused for 5-6 min, filtered through an ashless filter. The test tube was filled with filtered meat and water extract in the amount of $2.0-2.5 \mathrm{~cm}^{3} ; 0.1-0.2 \mathrm{~cm}^{3}$ of an alcohol solution of chrome dark blue with a mass concentration of $0.3 \%$ was introduced with a graduated pipette, the content of the tube was shaken and after 2-3 s, the presence of a light purple color (positive reaction) was established - in the presence of treatment of the meat with alkaline disinfectants or light pink color (negative reaction) - in the absence of treatment of the meat with alkaline disinfectants.

The stability of the indicators for establishing the intensity of the presence of a light purple color (positive reaction) or the presence of a light pink color (negative reaction) during the establishment of the treatment of meat of slaughter animals with alkaline disinfectants was 99.9\%. Also, more reliable data - in $99.2-99.8 \%$ were obtained in comparison with the method of determining the content of amino-ammonia nitrogen and in 99.0-99.7\% - in the method of determining the content of microorganisms in the meat of slaughter animals (Bogatko, Konstantinov and Bogatko, 2016; SDVMMAPU, 2002).

Studies have shown treatment of slaughter meat with alkaline disinfectants according to the intensity of color in 33 samples: 10 samples of pork, 12 samples of beef, 6 samples of lamb, 5 samples of goat. The research results are presented in the Table 2.

Studies have shown that the largest number of samples treated with alkaline disinfectants (the presence of light purple color) was in beef $(n=5)$ and in pork $(n=4)$.

In the absence of adulteration with alkaline disinfectants, the presence of light pink color (negative reaction) was noted: in 7 samples of beef; in 6 samples of pork; in 4 samples of lamb and goat. 
Table 2 - Detection of meat of slaughter animals treated with alkaline disinfectants by color intensity using chrome dark blue $(\mathrm{n}=33)$

\begin{tabular}{|l|c|c|}
\hline \multirow{2}{*}{$\begin{array}{c}\text { Type } \\
\text { of } \\
\text { meat }\end{array}$} & \multicolumn{2}{|c|}{ Indicators of color intensity } \\
\cline { 2 - 3 } & $\begin{array}{c}\text { adulteration } \\
\text { (positive reaction) }\end{array}$ & $\begin{array}{c}\text { no adulteration } \\
\text { (negative reaction) }\end{array}$ \\
\cline { 2 - 3 } & light purple color & light pink color \\
\hline Pork, $\mathrm{n}=10$ & $\mathrm{n}=4$ & $\mathrm{n}=6$ \\
\hline Beef, $\mathrm{n}=12$ & $\mathrm{n}=5$ & $\mathrm{n}=7$ \\
\hline Lamb, $\mathrm{n}=6$ & $\mathrm{n}=2$ & $\mathrm{n}=4$ \\
\hline Goat, $\mathrm{n}=5$ & $\mathrm{n}=1$ & $\mathrm{n}=4$ \\
\hline
\end{tabular}

The essence of the method of detecting intentional treatment with alkaline detergents of slaughter animals is to use an alcoholic solution of bromocresol green with a mass concentration of $0.01 \%$, which when interacting with alkaline detergents forms a blue compound that will ensure the reliability of safety and quality meat (Bogatko, Fotina and Yatsenko, 2019c).

The task of the developed express method was solved by applying to the surface of muscle tissue of pork, beef, lamb, goat with an area of $2.0 \times 2.5 \mathrm{~cm}$ with a graduated pipette $0.1-0.2 \mathrm{~cm}^{3}$ of an alcohol solution of bromocresol green with a mass concentration of $0.01 \%$ and after $1-2 \mathrm{~s}$ the presence of a blue color (positive reaction) - in the presence of treatment of the meat with alkaline detergents or the presence of a green color (negative reaction) - in the absence of treatment of the meat with alkaline detergents was set.

The reliability of the developed method for determining the adulteration of meat of slaughter animals and poultry by treatment with alkaline detergents using bromocresol green when determining the intensity of the presence of blue color (positive reaction) or the presence of green color (negative reaction) was $99.9 \%$.

The stability of the indicators for determining the intensity of the presence of a blue color (positive reaction) or the presence of a green color (negative reaction) during the establishment of the treatment of the meat of slaughter animals with alkaline detergents was $99.9 \%$. Also, more reliable data - in $98.9-99.7 \%$ obtained in comparison with the method of determining the content of aminoammonia nitrogen and in 99.1-99.8\% — in the method of determining the content of microorganisms in the meat of slaughter animals (Bogatko, Konstantinov and Bogatko, 2016; SDVMMAPU, 2002).

Studies have revealed the treatment of the meat of slaughter animals with alkaline disinfectants according to the intensity of color in 36 samples: 12 samples of pork, 12 samples of beef, 6 samples of lamb, 6 samples of goat. The results of the developed method are presented in the Table 3. Studies have shown that the largest number of samples treated with alkaline detergents (blue) was in pork $(\mathrm{n}=5)$, beef $(\mathrm{n}=4)$ and lamb $(\mathrm{n}=3)$.
Table 3-Detection of meat of slaughter animals treated with alkaline detergents by color intensity using bromocresol green $(\mathrm{n}=36)$

\begin{tabular}{|l|c|c|}
\hline \multirow{2}{*}{$\begin{array}{c}\text { Type } \\
\text { of } \\
\text { meat }\end{array}$} & \multicolumn{2}{|c|}{ Indicators of color intensity } \\
\cline { 2 - 3 } & $\begin{array}{c}\text { adulteration } \\
\text { (positive reaction) }\end{array}$ & $\begin{array}{c}\text { no adulteration } \\
\text { (negative reaction) }\end{array}$ \\
\cline { 2 - 3 } & blue color & green color \\
\hline Pork, $\mathrm{n}=12$ & $\mathrm{n}=5$ & $\mathrm{n}=7$ \\
\hline Beef, $\mathrm{n}=12$ & $\mathrm{n}=4$ & $\mathrm{n}=8$ \\
\hline Lamb, $\mathrm{n}=6$ & $\mathrm{n}=3$ & $\mathrm{n}=3$ \\
\hline Goat, $\mathrm{n}=6$ & $\mathrm{n}=2$ & $\mathrm{n}=4$ \\
\hline
\end{tabular}

In the absence of adulteration with alkaline detergents, the presence of green color (negative reaction) was noted: in 8 samples of beef; in 7 samples of pork; in 4 samples of goat, and in 3 samples of lamb.

The essence of the method of detection of intentional treatment with alkaline detergents of meat of slaughter animals is to use an alcoholic solution of bromothymol blue with a mass concentration of $0.04 \%$, which when interacting with alkaline detergents forms a dark blue compound of varying intensity depending on the level of treatment, respectively $-\leq 5.0 \%$ and $\geq 5.1 \%$, which will ensure the reliability of the results for determining the safety and quality of meat (Bogatko et al., 2017b).

The task of the developed express method was solved by applying on the surface of the muscle tissue of pork, beef, lamb, goat with an area of $2.0 \times 2.5 \mathrm{~cm}$, with a graduated pipette $0.2-0.3 \mathrm{~cm}^{3}$ alcohol solution of bromothymol blue with mass concentration of $0.04 \%$, and after 2-3 s we set the presence of light yellow color (negative reaction) or the presence of dark blue color of different intensity depending on the amount of alkaline detergents: light blue color (positive reaction) - the presence of alkaline detergents funds on the surface of muscle tissue $\leq 5.0 \%$; dark blue color (positive reaction) - the presence of alkaline detergents on the surface of muscle tissue $\geq 5.1 \%$.

The stability of indicators on intensity of dark blue color of various intensity depending on the amount of alkaline detergents to $\leq 5.0 \%$ and $\geq 5.1 \%$ (positive reactions) or existence of light yellow color (negative reaction) when determining processing of meat of slaughter animals by alkaline detergents was $99.9 \%$. Also, more reliable data - in 98.5-99.6\% obtained in comparison with the method of determining the content of amino-ammonia nitrogen and in $98.7-99.5 \%$ - in the method of determining the content of microorganisms in the meat of slaughter animals (Bogatko, Konstantinov and Bogatko, 2016; SDVMMAPU, 2002).

Studies have revealed the treatment of meat of slaughter animals with alkaline detergents according to the intensity of color in 36 samples: 12 samples of pork, 12 samples of beef, 6 samples of lamb, 6 samples of goat. 
The research results are presented in the Table 4. Studies have shown that the largest number of samples treated with alkaline detergents by their applying $\leq 5.0 \%$ was in beef $(n=3)$ and by applying $\geq 5.1 \%$ was in pork $(n=4)$ and goat $(\mathrm{n}=4)$.

Table 4- Detection of meat of slaughter animals treated with alkaline detergents by color intensity using bromothymol blue $(\mathrm{n}=36)$

\begin{tabular}{|c|c|c|c|}
\hline \multirow{3}{*}{$\begin{array}{c}\text { Type } \\
\text { of } \\
\text { meat }\end{array}$} & \multicolumn{3}{|c|}{ Indicators of color intensity } \\
\hline & \multicolumn{2}{|c|}{$\begin{array}{c}\text { adulteration } \\
\text { (positive reaction) }\end{array}$} & \multirow{2}{*}{\begin{tabular}{|c|}
$\begin{array}{c}\text { no adulteration } \\
\text { (negative } \\
\text { reaction) }\end{array}$ \\
light \\
yellow \\
color
\end{tabular}} \\
\hline & $\begin{array}{c}\text { light blue } \\
\text { color } \\
(\leq 5.0 \%)\end{array}$ & $\begin{array}{c}\text { dark blue } \\
\text { color } \\
(\geq 5.1 \%)\end{array}$ & \\
\hline Pork, $n=12$ & $\mathrm{n}=2$ & $\mathrm{n}=4$ & $\mathrm{n}=6$ \\
\hline Beef, $n=12$ & $\mathrm{n}=3$ & $\mathrm{n}=1$ & $\mathrm{n}=8$ \\
\hline Lamb, $n=6$ & $\mathrm{n}=1$ & $\mathrm{n}=3$ & $\mathrm{n}=2$ \\
\hline Goat, $\mathrm{n}=6$ & $\mathrm{n}=1$ & $\mathrm{n}=4$ & $\mathrm{n}=1$ \\
\hline
\end{tabular}

In the absence of adulteration with alkaline detergents - the absence of dark blue color of varying intensity, but in the presence of light yellow (negative reaction) in 6 samples of pork, 8 samples of beef, 2 samples of lamb, 1 sample of goat.

The essence of the method of detecting treatment with alkaline disinfectants of meat of slaughter animals is to use an alcoholic solution of rosolic acid with a mass concentration of $0.25 \%$, which when interacting with alkaline disinfectants forms a crimson red compound of varying intensity depending on the number of treatments $\leq 5.0 \%$ and $\geq 5.1 \%$, which will ensure the reliability of the results for determining the safety and quality of meat (Bogatko et al., 2017a).

The task of the developed express method was solved by applying on the surface of the muscle tissue of pork, beef, lamb, goat with an area of $2.0 \times 2.5 \mathrm{~cm}$, using a graduated pipette $0.1-0.2 \mathrm{~cm}^{3}$ of alcoholic solution of rosolic acid with mass concentration of $0.25 \%$, and after 1-2 s we set the presence of light yellow or brown yellow color (negative reaction) or the presence of crimson red color of different intensity depending on the amount of alkaline disinfectants: light crimson color (positive reaction) - the presence of alkaline disinfectants on the surface of muscle tissue $\leq 5.0 \%$; crimson red color (positive reaction) - the presence of alkaline disinfectants on the surface of muscle tissue $\geq 5.1 \%$.

The stability of indicators of crimson red color intensity depending on the amount of alkaline disinfectants $\leq 5.0 \%$ and $\geq 5.1 \%$ (positive reactions) or presence of light yellow or brown yellow color (negative reaction) when detecting the treatment of meat of slaughter animals with alkaline disinfectants was $99.9 \%$.

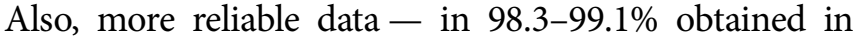
comparison with the method of determining the content of amino-ammonia nitrogen and in $98.4-99.5 \%$ - in the method of determining the content of microorganisms in the meat of slaughter animals (Bogatko, Konstantinov and Bogatko, 2016; SDVMMAPU, 2002).

Studies have revealed treatment of slaughter animals' meat with alkaline disinfectants according to color intensity in 33 samples: 10 samples of pork, 12 samples of beef, 6 samples of lamb, 5 samples of goat. The research results are presented in the Table 5 .

Table 5- Detection of meat of slaughter animals treated with alkaline disinfectants by color intensity using rosolic acid $(\mathrm{n}=33)$

\begin{tabular}{|l|c|c|c|}
\hline \multirow{4}{*}{$\begin{array}{c}\text { Type } \\
\text { of } \\
\text { meat }\end{array}$} & \multicolumn{2}{|c|}{$\begin{array}{c}\text { Indicators of color intensity } \\
\text { (positive reaction) }\end{array}$} & $\begin{array}{c}\text { no adulteration } \\
\text { (negative } \\
\text { reaction) }\end{array}$ \\
\cline { 2 - 4 } & $\begin{array}{c}\text { light crimson } \\
\text { color } \\
(\leq \mathbf{5 . 0 \% )}\end{array}$ & $\begin{array}{c}\text { crimson } \\
\text { red color } \\
(\geq \mathbf{5 . 1 \% )}\end{array}$ & $\begin{array}{c}\text { light yellow or } \\
\text { brown yellow } \\
\text { color }\end{array}$ \\
\hline Pork, $\mathrm{n}=10$ & $\mathrm{n}=2$ & $\mathrm{n}=4$ & $\mathrm{n}=4$ \\
\hline Beef, $\mathrm{n}=12$ & $\mathrm{n}=1$ & $\mathrm{n}=5$ & $\mathrm{n}=6$ \\
\hline Lamb, $\mathrm{n}=6$ & $\mathrm{n}=1$ & $\mathrm{n}=2$ & $\mathrm{n}=3$ \\
\hline Goat, $\mathrm{n}=5$ & $\mathrm{n}=4$ & $\mathrm{n}=\mathbf{n}$ & $\mathrm{n}=1$ \\
\hline
\end{tabular}

Studies have shown that the largest number of samples treated with alkaline disinfectants by applying $\leq 5.0 \%$ (the presence of light crimson color) was in goat $(\mathrm{n}=4)$, and the application of $\geq 5.1 \%$ (the presence of crimson red color) was in beef $(n=5)$ and pork $(n=4)$.

In the absence of adulteration with alkaline disinfectants - the absence of crimson red color of varying intensity, but in the presence of light yellow or brown yellow color (negative reaction) in 6 samples of beef; in 4 samples of pork; in 3 samples of lamb and in 1 sample of goat.

Conclusions. When treating the meat of slaughter animals with sodium bicarbonate solution using an alcoholic solution of chrome dark blue ( $0.5 \%)$, the number of samples was established: beef $(n=2)$, pork $(n=2)$ due to the application of $\leq 5.0 \%$ and beef $(n=4)$, pork $(\mathrm{n}=4)-\geq 5.1 \%$; for treatment with alkaline detergents when using an alcoholic solution of bromothymol blue $(0.04 \%)$ : beef $(n=3)$ due to the application of $\leq 5.0 \%$, and pork $(n=4)$ and goat $(n=4)-\geq 5.1 \%$; for treatment with alkaline disinfectants when using an alcoholic solution of rosolic acid ( $0.25 \%)$ : goat $(n=4)$ due to the application of $\leq 5.0 \%$, and beef $(n=5)$ and pork $(n=4)-\geq 5.1 \%$; for treatment with alkaline disinfectants when using an alcoholic solution of chrome dark blue $(0.3 \%)$ : beef $(n=5)$ and pork $(n=4)$; for treatment with alkaline detergents when using an alcoholic solution of bromocresol green 
(0.01\%): pork $(n=5)$, beef $(n=4)$ and lamb $(n=3)$. Developed patented express techniques with a test accuracy of $99.9 \%$ can be used to control hazardous chemical factors - the establishment of adulteration of meat of slaughter animals with a solution of sodium bicarbonate and alkaline detergents and disinfectants at facilities for the production and circulation of meat and meat products.

\section{References}

Aida, A. A., Che Man, Y. B., Wong, C. M. V. L., Raha, A. R. and Son, R. (2005) 'Analysis of raw meats and fats of pigs using polymerase chain reaction for Halal authentication', Meat Science, 69(1), pp. 47-52. doi: 10.1016/j.meatsci.2004.06.020.

Aksu, M. I., Kaya, M. and Ockerman, H. W. (2005) 'Effect of modified atmosphere packaging and temperature on the shelf life of sliced pastirma produced from frozen/thawed meat', Journal of Muscle Foods, 16(3), pp. 192-206. doi: 10.1111/j.17454573.2005.08404.x.

Amaral, J., Meira, L., Oliveira, M. B. P. P. and Mafra, I. (2016) 'Advances in authenticity testing for meat speciation', in Doewney, G. (ed.) Advances in Food Authenticity Testing. Elsevier, pp. 369-414. doi: 10.1016/B978-0-08-100220-9.00014-X.

Bogatko, N. M., Fotina, T. I. and Yatsenko, I. V. (2019a) Method for Detection of Slaughter Animals' Meat Adulteration by Treatment with Sodium Bicarbonate Using Chrome Dark Blue [Sposib vyznachennia falsyfikatsii miasa zabiinykh tvaryn za obrobky rozchynom hidrokarbonatu natriiu iz zastosuvanniam khromovoho temno-synoho]. Patent no. UA 132813. Available at: https://base.uipv.org/searchINV/search.php?action=viewdetails \&IdClaim=256491. [in Ukrainian].

Bogatko, N. M., Fotina, T. I. and Yatsenko, I. V. (2019b) Method for Detection of Slaughter Animals' Meat Adulteration by Treatment with Alkaline Disinfectants Using Chrome Dark Blue [Sposib vyznachennia falsyfikatsii miasa zabiinykh tvaryn za obrobky luzhnymy dezinfikuiuchymy zasobamy iz zastosuvanniam khromovoho temno-synoho]. Patent no. UA 132814. Available at: https://base.uipv.org/searchINV/search. php?action=viewdetails\&IdClaim=256492. [in Ukrainian].

Bogatko, N. M., Fotina, T. I. and Yatsenko, I. V. (2019c) Method for Detection of Slaughter Animals' Meat Adulteration by Treatment with Alkaline Detergents Using Bromocresol Green [Sposib vyznachennia falsyfikatsii miasa zabiinykh tvaryn za obrobky luzhnymy myinymy zasobamy iz zastosuvanniam bromkrezolovoho zelenoho]. Patent no. UA 132815. Available at: https://base.uipv.org/searchINV/search.php?action=viewdetails \&IdClaim=256493. [in Ukrainian].

Bogatko, N. M., Konstantinov, P. D. and Bogatko, L. M. (2016) Veterinary and Sanitary Examination of Meat of Slaughter Animals, Poultry, Rabbits: Guidelines [Veterynarno-sanitarna ekspertyza miasa zabiinykh tvaryn, sviiskoi ptytsi, kroliv: metodychni rekomendatsii]. Bila Tserkva: Bila Tserkva National Agrarian University. [in Ukrainian].

Bogatko, N. M., Melnik, A. Yu., Serdiukov, Ya. K., Bogatko, L. M. and Bogatko, A. F. (2017a) Method for Detection of Adulteration of Meat of Slaughter Animals and Poultry by Treatment with Alkaline Disinfectants [Sposib vyznachennia falsyfikatsii miasa zabiinykh tvaryn ta ptytsi za obrobky luzhnymy dezinfikuiuchymy zasobamy]. Patent no. UA 116830. Available at: https://base.uipv.org/searchINV/search.php?action=viewdetails \&IdClaim=236143. [in Ukrainian].

Bogatko, N. M., Melnik, A. Yu., Serdiukov, Ya. K., Bogatko, L. M. and Bogatko, A. F. (2017b) Method for Detection of Adulteration of Meat of Slaughter Animals and Poultry by Treatment with Alkaline Detergents [Sposib vyznachennia falsyfikatsii miasa zabiinykh tvaryn ta ptytsi za obrobky luzhnymy myinymy zasobamy]. Patent no. UA 116831. Available at: https://base.uipv.org/searchINV/search.php?action=viewdetails \&IdClaim=236144. [in Ukrainian].

Carr, C. C., Scheffler, J. M. and Johnson, D. D. (2017) 'Categorizing processing via the Meat Science Lexicon', Animal Frontiers, 7(4), pp. 19-24. doi: 10.2527/af.2017.0438.

Fotina, T. I., Zapara, S. I., Fotina, H. A. and Fotin, A. V. (2016) 'HACCP system as pass for quality and safety of poultry products', Journal for Veterinary Medicine, Biotechnology and Biosafety, 2(3), pp. 19-22. Available at: http://jvmbbs.kharkov. ua/archive/2016/volume2/issue3/oJVMBBS_2016023_019-022. pdf.

Hulebak, K. L. and Schlosser, W. (2002) 'Hazard Analysis and Critical Control Point (HACCP) history and conceptual overview', Risk Analysis, 22(3), pp. 547-552. doi: 10.1111/02724332.00038 .

Manning, L. and Soon, J. M. (2014) 'Developing systems to control food adulteration', Food Policy, 49(1), pp. 23-32. doi: 10.1016/j.foodpol.2014.06.005.

Milios, K., Drosinos, E. H. and Zoiopoulos, P. E. (2012) 'Factors influencing HACCP implementation in the food industry', Journal of the Hellenic Veterinary Medical Society, 63(4), pp. 283-290. doi: 10.12681/jhvms.15442.

Odewade, J. O., Oyelami, L. O. and Fasogbon, A. O. (2018) 'Microbial analysis of processed foods stored in domestic refrigerators of selected in Ile-Ife, Osun State, Nigeria', American Journal of Bioscience and Bioengineering, 6(3), pp. 21-26. doi: 10.11648/j.bio.20180603.11.

SDVMMAPU (The State Department of Veterinary Medicine of the Ministry of Agrarian Policy of Ukraine) (2002) Rules of Antemortem Veterinary Inspection of Animals and Veterinary-Sanitary Examination of Meat and Meat Products [Pravyla peredzabiinoho veterynarnoho ohliadu tvaryn $i$ veterynarno-sanitarnoi ekspertyzy miasa ta miasnykh produktiv]: approved by the Order of the State Department of Veterinary Medicine of the Ministry of Agrarian Policy of Ukraine No. 28 of June 7, 2002; registered in the Ministry of Justice of Ukraine with No. 524/6812 of on June 21, 2002. Available at: https://zakon.rada.gov.ua/laws/z0524-02. [in Ukrainian]. 